\title{
THE ELABORATION PROCESS OF AN EDUCATIONAL GUIDE FOR INDIVIDUALS WITH AN OSTOMY: DEVELOPMENT OF EDUCATIONAL GUIDELINES FOR THE SELF-CARE OF PATIENTS WITH AN INTESTINAL AND/OR URINARY OSTOMY
}

\author{
PROCESSO DE ELABORAÇÃO DE GUIA EDUCACIONAL PARA ESTOMIZADOS: \\ CONSTRUÇÃO DE GUIA EDUCATIVO PARA O AUTOCUIDADO DE PESSOAS \\ COM ESTOMA INTESTINAL E/OU URINÁRIO
}

\author{
Selma de Andrade COELHO ${ }^{1}$; Denise Regina da Costa AGUIAR ${ }^{2}$ \\ 1. Universidade Camilo Castelo Branco, Fernandópolis, SP, Brasil; 2. Universidade Camilo Castelo Branco, Fernandópolis, SP, Brasil.
}

\begin{abstract}
This study aimed to develop a guideline concerning the care directed toward an individual with an intestinal and/or urinary ostomy attending the Assistance Service for Ostomized Patients implemented at the Clinical Hospital of Uberlândia UFU, in order that such individuals be provided the means of self-care and thus improve their life quality. A bibliographical survey was performed on the theme, which focused on Guidelines Based on Evidence. The development of these guidelines was based on a bibliographical survey and took as its foundation the principles of Orem's self-care theory and the educational practices applied to pedagogy in health according to Paulo Freire's philosophy concerning liberating education, qualification and dialogue between the subject and the professional, which grants the possibility of aiding the family and patient to modify their lifestyles and be the agents of transformation, thus favoring the development of their autonomy. The printed educational material brings new information and knowledge to the ostomized patient.
\end{abstract}

KEYWORDS: Ostomy. Nursing. Education in health. Self-care. Educational technology.

\section{INTRODUCTION}

The ostomy or stoma, a word of Greek origin, which means mouth, opening is performed through surgical intervention in an attempt to compensate the functioning of an organ affected by some kind of disease, whereby the communication of this organ is reestablished with the external environment (BORGES; RIBEIRO, 2015).

Colorectal cancer (CRC) is the main reason for creating a stoma in an oncological patient. In epidemiological terms, it represents the third most common neoplasia in both sexes and the second cause in developed countries (INCA, 2018).

An estimated 17,380 new cases of colon and rectum cancer in men and 18,980 in women for each year are estimated for Brazil in the biennium 20182019. These values correspond to an estimated risk of 16.83 new cases per 100,000 men and 17.90 per 100,000 women (INCA, 2018).

Surgical intervention with the objective of creating an opening generates, in the ostomized individual and their family members, a type of invasion concerning physical, psychological and social intimacies, besides changes to their daily habits, bringing significant impacts to the lives of those that are affected by such a condition. Some impacts of this category are: lack of fecal and urinary control, the need to use a collector bag to store drained material, loss of control over the elimination of gases, alterations to ones self-image and self-esteem as well as producing biopsychosocial imbalance (CESARETTI; LEITE, 2000).

In order to minimize these impacts, the federal and state governments have over recent decades advanced in promoting the rights of individuals with disabilities ${ }^{1}$ by means of public

\footnotetext{
"Art. 4 A disabled individual is considered one that fits into the following categories: I - physical disability - complete or partial alteration of one or more segments of the human body, leading to impairment of physical function, presenting itself under the forms of paraplegia, paraparesis, monoplegia, monoparesis, tetraplegia, tetraparesis, triplegia, triparesis, hemiplegia, hemiparesis, ostomy, amputation or absence of a member cerebral palsy, dwarfism, limbs with congenital or acquired deformity, except aesthetic deformities and those that do not produce difficulties for performing functions; (As amended by Decree N ${ }^{0} 5.296$, of 2004) II - auditory deficiency bilateral, partial or total loss, of forty-one decibels $(\mathrm{dB})$ or more, measured by audiogram in the frequencies of $500 \mathrm{HZ}, 1.000 \mathrm{HZ}$, $2.000 \mathrm{~Hz}$ and $3.000 \mathrm{~Hz}$; (As amended by Decree $\mathrm{N}^{\circ} 5.296$, of 2004) III - visual deficiency - blindness, in which visual acuity is equal to or less than 0.05 in the better eye, with the best optical correction; low vision which means visual acuity between 0.3 and 0.05 in the better eye, with the best optical correction; those cases where the sum of the average field of vision in both eyes is equal or less than $60^{\circ}$; or the simultaneous occurrence of any of the aforementioned conditions; (As amended by Decree $\mathrm{N}^{\mathrm{o}} 5.296$, of 2004) IV - mental disability intellectual functionality significantly inferior to the average with manifestations before the age of eighteen years and limitations associated with two or more areas of adaptive ability, such as: a) communication; b) personal care; c) social habits; d) use of
} 
The elaboration...

policies that seek to value the person as a citizen, through respecting their characteristics and individuality.

Some of the main decrees, ordinances and resolutions concerning ostomized individuals ${ }^{2}$ published by the federal union and states are: Decree law No 3.298, of 20 December 1999, that went on to consider the ostomized individual as physically disabled (BRASIL, 1999); Decree $\mathrm{N}^{\circ}$ 5.296, of 2 December 2004,that establishes general standards and basic criteria for promoting accessibility of physically disabled individuals or those with reduced mobility (BRASIL, 2004); Ordinance MS No 400, of 16 November 2009, that establishes National Guidelines for the Assistance Service for Ostomized Patients within the SUS environment (BRASIL, 2009); Ordinance MS N ${ }^{\circ}$ 4.279, of 30 December 2010, which established the Health Assistance Networks (HAN) (BRASIL, 2010); Ordinance GM/MS No 793, of 24 April 2012 (BRASIL, 2012); and Resolution CIB/SUS/MG N ${ }^{\circ}$ 1.272 , of 24 October 2012, which instituted the Network of Care for Disabled Individuals from SUS-MG (SES-MG, 2012).

However, public policies look to establishing basic criteria for promoting access, define duties, offer specialized assistance and education for self-care and the evaluation of biopsychosocial needs focused on the adaptation from the point of view of the ostomized individual.

In parallel with public policies, there exist organizations that are directed toward the ostomized individual, due to the great importance concerning the fight for social rights and the continual search to guarantee resources for implementing policies favorable to ostomized individuals.

However, when one observes the course taken over the years, one notes that the Federal constitution of 1988, even with its guarantees of a quality assistance to these individuals, still does not encompass many of the aspects necessary for an improved and effective quality of services delivered,

community resources; (As amended by Decree $\mathrm{N}^{\circ} 5.296$, of 2004) e) health and safety; f) academic abilities; g) leisure; and h) work; V multiple deficiency - association of two or more deficiencies." (BRASIL, 1999)

${ }^{2}$ In accordance with the norms of transmutation of Greek terms into Portuguese, ostomy is of irregular form. Neither "ostoma" nor "ostomia" are found in the dictionary, although this may change in the future, if these words take on a more widespread use. In the Portuguese language, the forms derived from the Greek term stóma, mouth, when starting a word are written with an initial $e$ (estoma), not $o$ (ostoma). From such come the terms estomalgia, estomatite and estomódio. As a rule, though there do exist exceptions, in the making of names with elements coming from Greek or from Latin, one uses the referred prosthetic $e$ before terms initiated with $\mathrm{s}$, followed by another consonant.
COELHO, S. A.; AGUIAR, D. R. C. et al.

which thus give the impression of fragmented support.

In this process, the nurse, in the sense of health educator, plays an important role of conducting the plan of assistance directed toward the promoting of health, and through educational activities guides the patient through the use of resources the making of decisions on their very own self-care, along with health practices adjusted to their new life condition (MARTINS; ALVIM, 2011).

In the context of self-care, the nurse performs a privileged role in the health team, as they collaborate in the definition of educational strategies and directives concerning the support resources that can respond to the needs of the individual that lives with an ostomy, thus promoting their independence and autonomy.

According to Reveles and Takahashi (2007), educational technology produced in the context of health education is of fundamental importance, as this resource promotes self-care abilities, as well as patient autonomy. However, the authors suggest that each institution should develop their own manuals in accordance with regional and local characteristics, such as the question of foods typical of each particular region. This reinforces the importance of attending to the needs of ostomized patients, in a manner that improves the quality of assistance given by means of the instruments that provide the patient with a more refined form of care, clarify doubts from the patient and family members, and principally elevate the patient's self-esteem, with a sharp focus on the guidance manuals for ostomized patients, while using adequate presentation and accessible language

In Uberlândia, a city in Minas Gerais, the Service of Assistance to the Ostomized patient has registered 500 users, but does not count on any printed educational material. Therefore, the suggestion has been made as to the elaboration of an educational technology (guide) as a strategy and therapeutic support instrument, which contains specific guidance concerning the care related to the individual with an intestinal and/or urinary ostomy.

The process of producing the educational guide and directives for the individual with an intestinal and/or urinary ostomy takes as its base the principles of Dorothea Orem concerning the theory of self-care and educational practices applied to health pedagogy founded on Freirean thinking. Such a process provides the means through which the patient and family can modify their life styles, and be the agents of transformation with the objective of developing their autonomy. 
The elaboration...

The tools used by the care-giver, in the case of nurses, with the aim of empowering toward selfcare, one finds the educational practices that allow for a discussion in the search of better life quality for the patients and alternative means for minimizing injuries, which compromise health and are pronounced and sharpened through social inequality (MENEZES; ROSA, 2004).

In a general sense and in a specific sense for the ostomized client, self-care needs the partnership between the patient and professional to occur in an efficient manner, since it is possible to establish a relationship of trust, with the objective of developing a therapeutic plan together that attends to the needs of the patient in a complete fashion (SAMPAIO et al., 2008).

Therefore, according to Paulo Freire, education that liberates considers the reality of the student, their life experience and of the very facilitator/educator/professional, offering the opportunity of the individual to intervene in their own world. The idea of parting information upon those that receive it and its memorization is lost, thus providing the opportunity for one to become the builder of a new reality (CUNHA; BACKES; HEIDEMANN, 2012). In such a reality, the transformation and construction of democratic learning is performed at the rate which there exists dialogue between the subjects, and consequently facilitated by the educator (FREIRE, 2005).

This study aimed to develop a guideline concerning the care directed toward an individual with an intestinal and/or urinary ostomy attending the Assistance Service for Ostomized Patients implemented at the Clinical Hospital of Uberlândia UFU, in order that such individuals be provided the means of self-care and thus improve their life quality.

\section{MATERIAL AND METHODS}

This is essentially a bibliographical research by means of which were made various consultations of national and international Literature relevant to the subject that provided the means and founded the possibility of expanding the educational material.

The procedure performed in the study occurs in six distinct stages, of which five correspond to the bibliographical survey and the last the elaboration of the educational material.

The first stage of the bibliographical survey was performed by electronic means by searching the Latin-American Literature databases in Health Sciences (Lilacs), Scientific Electronic Library Online (Scielo) Brazil, The Spanish Bibliographical
COELHO, S. A.; AGUIAR, D. R. C. et al.

Index of Health sciences (Ibecs), Medline and Cumulative Index to Nursing and Allied Health Literature (Cinahl). For the composition of the search strategy, definition and use was made of the following descriptors and their combination in the Portuguese and English languages: education, nursing, surgical ostomy, guide and health. Consideration was given to articles published in Portuguese, English and Spanish during the period of 2005 to 2015.

In the second stage, national and international guides were researched that counseled ostomized individuals through the global organization known as the World Council of Enterostomal Therapists (WCET), an international source concerning ostomies.

In the third stage, a survey was performed on guides published among the manufacturers of materials for ostomized individuals.

In the fourth and five stage, some dissertations were identified concerning the creation of guides for directing ostomized individuals. Therefore, the bibliographical survey of the guidelines was performed based on evidence.

In the sixth and last stage, the guides were elaborated by means of the association of the bibliographical survey based on the principles of the self-care theory from Orem and educational practices applied to pedagogy in heath founded on the teachings of the educator Paulo Freire. Thus, addressing liberation through education, by the qualification and dialogue between the subject and the professional, with the means to aid the family and patient to modify their life style and be the agents of transformation, while benefitting the development of their autonomy.

\section{RESULTS AND DISCUSSION}

In the bibliographical survey, 31 references were found in the databases, however, three articles in the non-selected language, three articles not available online and five articles were repeated, according to Figure 1. 


Records identified through database search:
Lilacs $(\mathrm{n}=3)$

Records identified through database search:
Scielo $(\mathrm{n}=1)$

Records identified through database search: Ibecs $(n=2)$
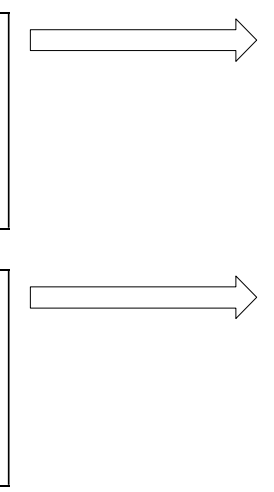

Records identified through database search: Medline $(n=23)$

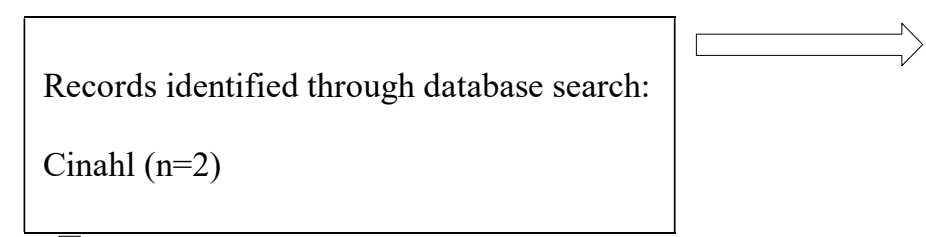

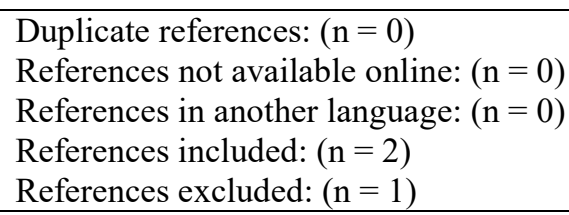

\section{Duplicate references: $(\mathrm{n}=0)$}

References not available online: $(n=0)$

References in another language: $(n=0)$

References included: $(\mathrm{n}=1)$

References excluded: $(n=0)$
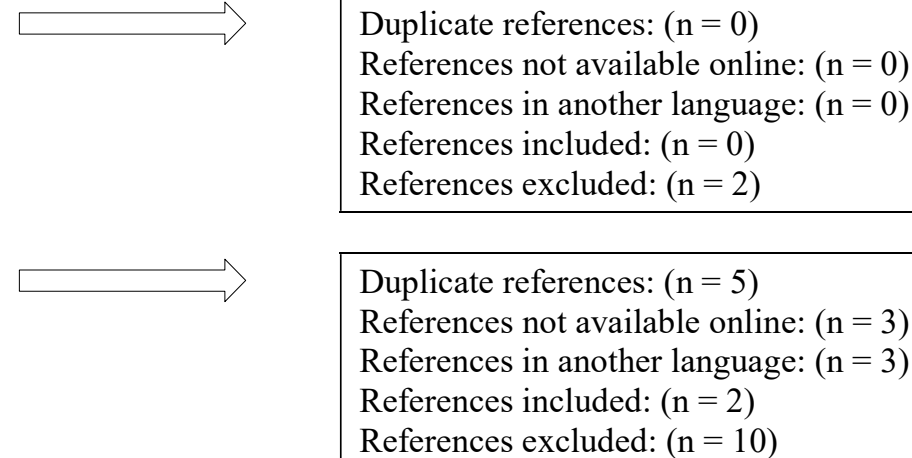

Duplicate references: $(n=5)$

References not available online: $(n=3)$

References in another language: $(n=3)$

References included: $(n=2)$

References excluded: $(\mathrm{n}=10)$

Duplicate references: $(\mathrm{n}=0)$

References not available online: $(n=0)$

References in another language: $(n=0)$

References included: $(\mathrm{n}=1)$

References excluded: $(n=1)$

Were included: 6 articles

Figure 1. Flowchart of articles in their databases

In terms of the results from the second stage, for the verification of national and international production of manuals/guides/booklets already published on the topic, the search on the global organization site WCET reveals 33 associations affiliated to the organ, with their respective electronic addresses, available to the public at www.wcetn.org/useful-link. By applying the inclusion criteria to the 33 associations - articles related to intestinal and/or urinary ostomies, written in English or Spanish and directed toward individuals with an ostomy -, only eight guides were used in this study. The result from the national manuals, guides and booklets is demonstrated on Table 1 . 
Table1. Result from national manuals, guides and booklets, according to electronic address, name/title, page number, edition and year.

\begin{tabular}{|c|c|c|c|c|}
\hline Electronic address & Name of booklet & $\begin{array}{c}\text { Page } \\
\text { number }\end{array}$ & Edition & Year \\
\hline $\begin{array}{l}\text { http://www1.inca.gov.br/inca/Arquivos/c } \\
\text { uidados_com_a_sua_estomia.pdf }\end{array}$ & Taking Care of your ostomy & 20 & 1 st & 2010 \\
\hline $\begin{array}{l}\text { http://www.abraso.org.br/cartilha_jovem } \\
\text { _ostomizado.pdf }\end{array}$ & Booklet for the ostomized youth & 48 & 1 st & 2004 \\
\hline $\begin{array}{l}\text { http://www.abraso.org.br/Cartilha\%20ho } \\
\text { mem\%20ostomizado.pdf }\end{array}$ & & 27 & 1 st & 2004 \\
\hline $\begin{array}{l}\text { http://www.abraso.org.br/Cartilha\%20O } \\
\text { stomizado\%20Jo\%C3\%A3o\%20Alberto } \\
\text {.pdf }\end{array}$ & João Alberto has an ostomy & 32 & 1 st & 2006 \\
\hline $\begin{array}{l}\text { http://www.abraso.org.br/Cart_Mulher_ } \\
\text { Ostomizada_4ed.pdf }\end{array}$ & $\begin{array}{l}\text { To the ostomized woman you } \\
\text { can still maintain your charm }\end{array}$ & 32 & $1 \mathrm{st}$ & 2009 \\
\hline $\begin{array}{l}\text { http://www.abraso.org.br/Cartilha\%20da } \\
\% 20 \text { Mulher\%20Ostomizada } \% 206 \% \text { C2 }\end{array}$ & $\begin{array}{l}\text { To the ostomized woman you } \\
\text { can still maintain your charm }\end{array}$ & 24 & 6 th & 2013 \\
\hline $\begin{array}{l}\text { \%AA\%20edi\%C3\%A7\%C3\%A3o.pdf } \\
\text { http://www.fegest.org/ }\end{array}$ & $\begin{array}{l}\text { The guide for the ostomized } \\
\text { individual }\end{array}$ & & & \\
\hline $\begin{array}{l}\text { http://www.saude.mg.gov.br/images/noti } \\
\text { cias_e_eventos/000_2016/2-abr-mai- } \\
\text { jun/ostomizados/24-06-Linha-de- } \\
\text { Cuidados-da-Pessoa-Estomizada.pdf }\end{array}$ & $\begin{array}{l}\text { Line of care for the person with } \\
\text { an ostomy }\end{array}$ & 136 & 1 st & 2015 \\
\hline
\end{tabular}

In the third stage, the survey of educational manuals/guides/booklets from the manufacturers that supply material to the Secretary of Health for the State of Minas Gerais (SES-MG) identified that, among the four suppliers, the companies Convatec, Coloplast and Hollister provide guides on their sites. In addition to these publications, three dissertations were found, with the following titles and objectives: Educational technology for promoting self-care in sexual health and reproductivity in ostomized women: a validation study, the study proposes the creation and validation of an educational health booklet as a nursing technology for promoting self-care in sexual health and reproductivity in ostomized women (ALBUQUERQUE, 2015); The ostomized senior citizen an attentive look: an educational gerontechnology proposal, with the objective to identify the characteristics of the ostomized senior citizen assisted at an ostomy-therapy service and proposes an educational gerontechnology that contributes to the care of the ostomized senior citizen (BARROS, 2007); and Educational technology for the ostomized individual: creating a guide directed to peristomal skin care, with the objective to create an educational technology (guide) concerning the care of peristomal skin (CARVALHO, 2014).
Our study proposal differs from the abovecited dissertations in that it is a guide toward the self-care of individuals with intestinal and/or urinary ostomy; it is similar to the above-mentioned in that all expand upon the idea of a guide, even though with different objectives for the ostomized adult.

In terms of the results of the fifth stage, identification was made as to five guidelines based on evidence: the Canadian guideline, Clinical Best Practice Guidelines, Ostomy Care and Management, published by the Registered Nurses' Association of Ontario (RNAO) in 2009 (RNAO, 2009); the American guideline developed by the Wound Ostomy and Continence Nurses Society (WOCN) (GOLDBERG et al., 2010), published in 2010; the Australian guideline, Clinical Guidelines: Stomal Therapy Nursing Practice (AASTN, 2013), published in 2013 by nurses from the Australian Association of Stomal Therapy Nurses Inc. (AASTN); and two English guidelines, Stoma Care National Clinical Guidelines (ASCN, 2016) and Guideline for Care of a Patient With a Stoma, from Nottingham University Hospitals (NHS) (TAYLOR, 2016), both published in 2016 .

After the analysis of the results, and in order to initiate the elaboration of the educational material, the researchers defined the themes that would go on to compose the guide, with the decision being made to incorporate the following items: front 
The elaboration...

cover, cataloguing data, summary, about the author, presentation of the guide, Orthosis and Prosthesis Concession Center - Ostomy HCU-UFU, rights and benefits of the ostomized individual, before surgery communication, after surgery communication, selfcare, speaking about the digestive/urinary system, learning about ostomies, bathing, work, leisure and travelling, social and family life, clothing, sexuality, speaking about food, getting to know the collector equipment, getting to know other materials, speaking about ostomy complications, changing the one-piece collector bag, changing two-piece collector bags, how to store material, what is irrigation, prevention, glossary, declaration, references, notes and back cover.

The researcher created content pertinent to each unit of the guidelines and healthcare norms for ostomized individuals and from the educational perspective of nursing care for ostomized individuals along with the promoting of self-care in accordance with the Orem theoretical model (FOSTER; BENETT, 2000), self-esteem, image of one's body and biopsychosocial impact of an ostomy in the life of ostomy patients

The texts were elaborated in Portuguese with the aim that these be coherent and comprehensible to the reader; a simple and basic language structure was incorporated, using short sentences, and paraphrased assimilations were used to describe technical terminologies in order to provide an accessible explanation to the intended audience.

The researcher used images from a personal databank. For some illustrations, the researcher presented the ideas of how the drawings should be constructed, by means of illustration models selected from the internet, and then a graphics designer performed the work on an Abode illustrator, with the aim of adapting these to the desired context.

In addition, there was also mentioned the relevance of the guide for supporting patients that recently had surgery to create an ostomy, with the aim of helping these and their family in providing the necessary care.

According to Moreira, Nóbrega and Silva (2003), well-written material or information of easy understanding improves knowledge and satisfaction of the patient, aids in developing their attitudes and abilities, facilitates autonomy, encourages a better understanding and ability on the part of the patient when it comes to influencing their very own standard of health and favors decision making.

According to the educator Paulo Freire, the participation of the individual aimed at health
COELHO, S. A.; AGUIAR, D. R. C. et al.

improvement is made possible by means of health strategies recommended through promoting health, where the objective is to reintegrate the individuals into a social living framework (MENDES, 2011). In this context, the elaboration of strategies that allow individuals, with support from the State and representative associations, to have a better resolution and control of those factors that impair health is characterized as empowerment (TRENTINI; CUBAS, 2005).

Such processes, in terms of policies for ostomized individuals, for example, empowers the perception of the individual that there are new perspectives and favorable conquests concerning their health condition, which contributes to mitigating social isolation (MENDES, 2011).

The use of the pedagogical principles of Paulo Freire on the subject of liberating education and dialogue contribute so that individuals can understand their specific needs and demands, and in such a way become the builders of their new reality (CUNHA; BACKES; HEIDEMANN, 2012). However, the transformation and construction of democratic learning occurs to the extent that there is dialogue between the subjects, which is facilitated by the educator (FREIRE, 2005).

In this context, by considering the activities of nurses, the importance of support quality given in the Assistance Service of Ostomized Patients becomes evident. As an example one can highlight new technologies that are gradually inserted into the care process, which demands from the professionals the continuation of education learning to guarantee the quality of professionals in general (TRENTINI; CUBAS, 2005). In addition, there exists the continual education of the patient and their family, by use of resources from technological education, such as printed material, videos and demonstrations of procedures on care (VASCONCELLOS-SILVA; RIVERA; CASTIEL, 2003).

Following on from this study of creating educational material, the next step is considered as being the creation of the Educational and Informative Guide for Individuals with an Intestinal Ostomy and the Educational and Informative Guide for Individuals with a Urinary Ostomy. These can take on the role of instruments that mediate advice and information to ostomized individuals, to the family/care-giver and the nursing professionals, where these can be used as a partner in daily care, thus incentivizing self-care and contributing toward improving public policy and life quality.

In addition to favoring the transformation and building of democratic learning by means of liberating education, the guides can create 
The elaboration...

opportunities where the subject can intervene in their own world.

Therefore, the study demonstrates the need for this educational material, as a strategy in health education, to be published and made freely available to all ostomized patients from the referred service given the relevance of the advice and information contained in it. We also demonstrated that is necessary to develop other similar studies in different regions of the country, as a valuable and
COELHO, S. A.; AGUIAR, D. R. C. et al.

effective practice for guiding individuals with an intestinal and/or urinary ostomy.

The authors suggest in future studies the subjects are given greater participation, as it is understood that they are indispensable, by means of a focus on group dynamics to aid the process of creating printed educational material, as such dynamics portrays the needs lived and experienced by the patients.

RESUMO: Trata-se da elaboração de um guia de orientação sobre os cuidados com a pessoa com estoma intestinal e/ou urinária acolhida em um Serviço de Atenção à Pessoa Estomizada, para instrumentalizá-la para o autocuidado e favorecer melhorias em sua qualidade de vida. Realizado por meio de levantamento bibliográfico sobre a temática com foco nas Diretrizes Baseadas em Evidências. A elaboração ocorreu por meio da associação do levantamento bibliográfico e teve por base referencial os princípios da teoria de Orem sobre o autocuidado e das práticas educativas aplicadas à pedagogia da saúde com base nos ensinamentos freirianos sobre a educação libertadora, a qualificação e o diálogo entre o sujeito e o profissional, como subsídio à possibilidade de auxiliar família e paciente a modificarem seu estilo de vida e serem agentes de transformação, privilegiando o desenvolvimento da sua autonomia. O material educativo impresso possibilita novos conhecimentos e informações aos pacientes estomizados. educacional.

PALAVRAS-CHAVE: Estoma. Enfermagem. Educação em saúde. Autocuidado. Tecnologia

\title{
REFERENCES
}

AASTN - AUSTRALIAN ASSOCIATION OF STOMAL THERAPY NURSES. Clinical Guidelines for Stomal Therapy Nursing Practice. [S.1.]: AASTN, 2013. Disponível em: http://www.stomaltherapy.com/standards_guidelines.php. Acesso em: 30 nov. 2016.

\begin{abstract}
ALBUQUERQUE, A. F. L. L. Tecnologia educativa para promoção do autocuidado na saúde sexual e reprodutiva de mulheres estomizadas: estudo de validação. 2015. $171 \mathrm{f}$. Dissertação (Mestrado em Enfermagem) - Centro de Ciências da Saúde, Universidade Federal de Pernambuco, Recife, 2015. Disponível em: http://repositorio.ufpe.br/handle/123456789/15420. Acesso em: 30 nov. 2016.
\end{abstract}

ASCN - THE ASSOCIATION OF STOMA CARE NURSES UK. ASCN Stoma Care: National Clinical Guidelines. [S.1.]: ASCN UK, 2016.

BARROS, E. J. L. O ser idoso estomizado sob o olhar complexo: uma proposta de gerontotecnologia educativa. 2007. 126 f. Dissertação (Mestrado em Enfermagem) - Programa de Pós-graduação em Enfermagem, Universidade Federal do Rio Grande, Rio Grande, 2007. Disponível em:

http://repositorio.furg.br/handle/1/6372. Acesso em: 30 nov. 2016.

BORGES, E. L.; RIBEIRO, M. S. Linha de Cuidados da Pessoa Estomizada. Belo Horizonte: SES-MG, 2015. Disponível em: http://www.saude.mg.gov.br/cer/story/8453-ses-mg-lanca-linha-de-cuidados-da-pessoaestomizada. Acesso em: 21 fev. 2016.

BRASIL. Decreto no 3.298, de 20 de dezembro de 1999. Regulamenta a Lei ${ }^{\circ}$ 7.853, de 24 de outubro de 1989, dispõe sobre a Política Nacional para a Integração da Pessoa Portadora de Deficiência, consolida as normas de proteção, e dá outras providências. Disponível em: https://www.planalto.gov.br/ccivil_03/decreto/d3298.htm. Acesso em: 10 set. 2016. 
BRASIL. Decreto $\mathrm{n}^{0}$ 5.296, de 2 de dezembro de 2004. Regulamenta as Leis $\mathrm{n}^{\circ} 10.048$, de 8 de novembro de 2000, que dá prioridade de atendimento às pessoas que especifica, e 10.098, de 19 de dezembro de 2000, que estabelece normas gerais e critérios básicos para a promoção da acessibilidade das pessoas portadoras de deficiência ou com mobilidade reduzida, e dá outras providências. Disponível em:

http://portal.mec.gov.br/seesp/arquivos/pdf/decreto\%205296-2004.pdf. Acesso em: 10 set. 2016.

BRASIL. Ministério da Saúde. Portaria $\mathbf{n}^{0}$ 400, de 16 de novembro de 2009. Disponível em: http://bvsms.saude.gov.br/bvs/saudelegis/sas/2009/prt0400_16_11_2009.html. Acesso em: 13 out. 2016.

BRASIL. Ministério da Saúde. Portaria no 793, de 24 de abril de 2012. Institui a Rede de Cuidados à Pessoa com Deficiência no âmbito do Sistema Único de Saúde. Disponível em: http://bvsms.saude.gov.br/bvs/saudelegis/gm/2012/prt0793_24_04_2012.html. Acesso em: 13 out. 2016.

BRASIL. Ministério da Saúde. Portaria $\mathbf{n}^{\mathbf{0}}$ 4.279, de 30 de dezembro de 2010. Estabelece as diretrizes para organização da Rede de Atenção à Saúde no âmbito do Sistema Único de Saúde (SUS). Disponível em: http://bvsms.saude.gov.br/bvs/saudelegis/gm/2010/prt4279_30_12_2010.html. Acesso em: 13 out. 2016.

CARVALHO, D. S.. Tecnologia educacional para estomizados: construção de um guia de orientação para cuidados com a pele periestoma. 2014. 183 f. Dissertação (Mestrado Associado em Enfermagem) - Escola de Enfermagem "Magalhães Barata", Centro de Ciências Biológicas e da Saúde, Universidade do Estado do Pará, Belém, 2014. Disponível em: http://paginas.uepa.br/ppgenf/files/pdfs/DISSERTAO_DIONE_SEABRA.pdf. Acesso em: 30 nov. 2016.

CESARETTI, I. U. R.; LEITE, M. G. Bases para o cuidar em enfermagem. In: SANTOS, V. L.; CESARETTI, I. U. R. (Ed.). Assistência em estomaterapia: cuidando do estomizado. São Paulo: Atheneu, 2000.

CUNHA, R. R.; BACKES, V. M. S.; HEIDEMANN, I. T. S. B. Desvelamento crítico da pessoa estomizada: em ação o programa de educação permanente em saúde. Acta Paulista de Enfermagem, São Paulo, v. 25, n. 2, p. 296-301, mar./abr. 2012. http://dx.doi.org/10.1590/S0103-21002012000200022.

FOSTER, P. C.; BENETT, A. M.; DOROTHEA, E. O.. In: GEORGE, J. B. Teorias de enfermagem: os fundamentos à prática profissional. Ana Maria Vasconcellos Thorell (Trad). 4. ed. Porto Alegre: ARTMED, 2000. p. 83-102.

FREIRE, P. Pedagogia do oprimido. 46. ed. Rio de Janeiro: Paz e Terra, 2005. Disponível em: http://www.dhnet.org.br/direitos/militantes/paulofreire/paulo_freire_pedagogia_do_oprimido.pdf. Acesso em: 16 nov. 2016.

GOLDBERG, M.; AUKETT, L. K.; CARMEL, J.; FELLOWS, J.; FOLKEDAHL, B.; PITTMAN, J.; PALMER, R. Management of the Patient with a Fecal Ostomy: Best Practice for Clinicians. Journal of the Wound, Ostomy and Continence Nurses Society, Mount Laurel, v. 37, n. 6, p. 596-598, Nov./Dec. 2010. https://doi.org/10.1097/WON.0b013e3181f97e37.

INCA - INSTITUTO NACIONAL DE CÂNCER JOSÉ ALENCAR GOMES DA SILVA. Estimativa 2018: incidência de câncer no Brasil. Rio de Janeiro: INCA, 2018. Disponível em:

http://www1.inca.gov.br/estimativa/2018/sintese-de-resultados-comentarios.asp. Acesso em: 23 mar. 2019.

MARTINS, P. A. F.; ALVIM, N. A. T. Perspectiva educativa do cuidado de enfermagem sobre a manutenção da estomia de eliminação. Revista Brasileira de Enfermagem, Brasília, v. 64, n. 2, p. 322-327, mar./abr. 2011. http://dx.doi.org/10.1590/S0034-71672011000200016.

MENDES, E. V. As redes de atenção à saúde. Brasília: Organização Pan-Americana da Saúde, 2011. 
MENEZES, G. A. C.; ROSA, R. S. D. Práticas educativas em saúde: a enfermagem revendo conceitos na promoção do autocuidado. REME: Revista Mineira de Enfermagem, Belo Horizonte, v. 8, n. 2, p. 337-340, abr./jun. 2004. Disponível em: http://www.reme.org.br/artigo/detalhes/747. Acesso em: 13 out. 2016.

MOREIRA, M. F.; NOBREGA, M. M. L. da; SILVA, M. I. T.. Comunicação escrita: contribuição para a elaboração de material educativo em saúde. Revista Brasileira de Enfermagem, Brasília, v. 56, n. 2, p. 184188, mar./abr. 2003. http://dx.doi.org/10.1590/S0034-71672003000200015.

RNAO - REGISTERED NURSES' ASSOCIATION OF ONTARIO. Ostomy care and Management: Clinical Best Practice Guidelines. Toronto: Registered Nurses' Association of Ontario, 2009.

REVELES, A. G.; TAKAHASHI, R. T. Educação em saúde ao ostomizado: um estudo bibliométrico. Revista da Escola de Enfermagem da USP, São Paulo, v. 41, n. 2, p. 245-250, jun. 2007.

http://dx.doi.org/10.1590/S0080-62342007000200010.

SAMPAIO, F. A. A.; AQUINO, P. S.; ARAÚJO, T. L. de; GALVÃO, M. T. G. Assistência de enfermagem a paciente com colostomia: aplicação da teoria de Orem. Acta Paulista de Enfermagem, São Paulo, v. 21, n. 1, p. 107-111, jan./mar. 2008. http://dx.doi.org/10.1590/S0103-21002008000100015.

SES-MG - SECRETARIA DE ESTADO DE SAÚDE DE MINAS GERAIS. Deliberação no $\mathbf{1 . 2 7 2}$, de $\mathbf{2 4}$ de outubro de 2012. Institui a Rede de Cuidados à Pessoa com Deficiência SUS-MG e dá outras providências. Belo Horizonte, 24 out. 2012. Disponível em: http://www.saude.mg.gov.br/images/documentos/Deliberacao1272redesdecuidadosPessoacomdeficiencia.pdf. Acesso em: 10 set. 2016.

TAYLOR, J. Guideline for care of a patient with a stoma. Nottingham: Nottingham University Hospitals, 2016.

TRENTINI, M.; CUBAS, M. R. Ações de enfermagem em nefrologia: um referencial expandido além da concepção biologicista de saúde. Revista Brasileira de Enfermagem, Brasília, v. 58, n. 4, p. 481-485, jul./ago. 2005. http://dx.doi.org/10.1590/S0034-71672005000400020.

VASCONCELLOS-SILVA, P. R.; RIVERA, F. J. U.; CASTIEL, L. D. Comunicação instrumental, diretiva e afetiva em impressos hospitalares. Cadernos de Saúde Pública, Rio de Janeiro, v. 19, n. 6, p. 1667-1679, nov./dez. 2003. http://dx.doi.org/10.1590/S0102-311X2003000600011. 